\title{
Substitution Elasticities in the Large-Scale Manufacturing Industries of Pakistan
}

\author{
A. R. KEMAL ${ }^{*}$
}

This paper examines substitution elasticities between capital and labour in the manufacturing sector of Pakistan. It is found that whereas the substitution possibilities between the capital intensive and labour intensive techniques of production are rather limited, the substitution possibilities between various activities do exist. It is also found that changes in capital-labour ratio have a significant influence on the substitution elasticity and as such CES estimates, in general, are biased.

Factor-market distortions in Pakistan have reduced welfare by inducing 'wrong' specialisation and the adoption of capital-intensive techniques ill-suited to the country's factor endowments. These consequences of factor-market distortions are important because capital-intensive techniques of production and/or capital-intensive activities create far less job opportunities compared to the situation in which labour-intensive techniques of production are employed and/or country specialises in the labour-intensive activities. The removal of such distortions should, therefore, enhance social welfare by promoting a higher growth rate of GNP and by easing the unemployment problem. Thus a systematic exploration of the possibilities of factor substitution should be of considerable significance for economic analysis and policy making. If the elasticity of substitution is large, a small reduction in the relative prices of labour would lead to a rapid growth of employment. On the other hand, if it is low, the removal of distortions from the factor market will not have much effect on the choice of production techniques. Moreover, even if the substitution elasticity is low for each industry but is significantly high for the manufacturing sector as a whole, the appropriate changes in factor prices would lead to an increase in welfare by inducing specialisation in the right direction. Furthermore, a low substitution elasticity would imply a rather limited choice between production techniques, and as such it will highlight the importance and need of developing new and appropriate techniques. In view of these considerations, the importance of determining the magnitude of the relevant elasticities of substitution should be selfevident.

*The author is Chief of Research at the Pakistan Institute of Development Economics. He is deeply indebted to Professors Syed Nawab Haider Naqvi, A. K. Sen and T. N. Srinivasan for their helpful comments on an earlier draft of the paper. 
In this study, we shall estimate the elasticity of substitution for 16 different manufacturing sectors and for the large-scale manufacturing sector as a whole in order to see the role of relative prices in influencing the specialisation and the adoption of production techniques. We shall estimate the elasticities by specifying a VES production function. These estimates are also compared with those obtained by specifying the CES production function.

The plan of the paper is as follows. In the first section is reviewed the literature related to the estimation of substitution elasticities. In the second section, methodological and data problems are discussed. The estimates of substitution elasticity are reported in the third section, and then compared with those of other developing countries in the fourth section. Limitation of the analysis, policy implications, and major conclusions are summarised in the fifth, sixth and the seventh sections, respectively. In addition, there are two appendices in the paper. In Appendix I are discussed the general concepts of production functions and the elasticity of substitution derived from them. Appendix II presents detailed estimates of the production function.

\section{REVIEW OF THE LITERATURE}

To determine the possibilities of substitution between capital and labour in the developing countries, a number of studies have been made - for example, those by Roemer [21], Reynold and Gregory [20], Katz [11], Sicat [23], Oyelabi [18], Harris and Todaro [8], Diwan and Gujarati [7], Bruton [6], Rehman [19], Kazi et al. [12] , etc. ${ }^{1} \quad$ The elasticities of substitution have been estimated by using both the cross-section data and the time-series data. These studies show that the substitution elasticities for individual industries are generally lower than those for the manufacturing sector as a whole, while for a number of industries the elasticities have been very low, often insignificant. For example, Diwan and Gujarati [7] have found that in 17 out of the 28 Indian manufacturing industries which they studied, the elasticities of substitution were not significantly different from zero. Similar results have been reported for other countries as well. In the case of Pakistan, the only relevant study was done by Kazi et al. [12], which showed that the possibilities of substitution were rather limited for Pakistan as well.

An interesting finding of these studies is that, in general, the elasticities of substitution, estimated by using time series data, are lower than those obtained by using cross-section data. These results are plausible because of the dominance of the cyclical phenomenon and the simultaneity between the inputs used and the outputs produced in an industry, the time series estimates of the substitution elasticities impart a downward bias to the substitution elasticities. On the other hand, for the Bhalla [3], cross-section data the production function may not even be identified because the relative prices are not expected to vary systematically or unidirectionally across the firms; the differences in the input ratios across firms are due to factors other than the changes in relative prices of inputs. In view of the identification problem in a cross section study, we will limit ourselves in this study to the time-series analysis only.

The estimates of substitution elasticities for the other developing countries as well as for Pakistan have, in general, been obtained by fitting CES production functions, which implicitly assume that substitution elasticities are unaffected by changes in capital intensity. Hence, to the extent the elasticities are affected by changes in capital intensity, estimates obtained through CES will be biased both upwards and downwards. Hildebrand and Liu [9], Liu and Fletcher [16], Yeung and Tsiang [24], Sato [22] and others have developed VES production functions which allow the elasticity of substitution to vary with changes in the capital-labour ratios. Accordingly, VES production functions for the manufacturing industries of Pakistan have been fitted to obtain estimates of elasticities of substitution. This analytical strategy will permit us to determine the role of input prices in the adoption of capital-intensive techniques. Elasticity estimates have also been obtained by fitting the CES production function even though our major emphasis is on the VES production function. CES estimates are useful in the present study, firstly, to see the extent of bias in the elasticities of substitution across different industries due to CES production functions, and, secondly, to compare our results with previous studies and those for the other developing countries for which only CES estimates are available.

\section{METHODOLOGICAL AND DATA PROBLEMS}

Since both the CES and the VES production functions are highly non-linear, they cannot be estimated directly by the Ordinary Least Squares (OLS). However, they may be estimated directly either by non-linear techniques or by linearising the function. Alternatively, both the CES and the VES production functions can be estimated indirectly by postulating the relationship that marginal ptoduct of labour is equal to wages or that the marginal product of capital is equal to the interest rate. Because these methods are quite well known, we shall discuss them only briefly.

Non-linear maximum likelihood estimates of the CES production function, developed by Bodkin and Klein [4], are the estimates obtained through an iterative process which minimises the error sum of squares. However, because such maximum likelihood estimates are very sensitive to the choice of initial values of the parameters and are fraught with computational difficulties, direct estimation has not been used in this study. See Nadiri, [17].

CES production function may be directly estimated after linearising the function. Following Kmenta [15], we obtain the following relationship by expanding 
CES production function around $\rho=0$

$$
\operatorname{Ln}(V / L)=\operatorname{LnA}_{0}+(v \delta) \operatorname{LnL}+\mathrm{v}(1-\delta) \operatorname{Lnk}-1 / 2 \nu \rho \delta(1-\delta)(\mathrm{Lnk})^{2}
$$

where
$\mathrm{V}=$ Value added
$\mathrm{L}=$ Employment cost at constant prices of 1959-60,
$\mathrm{K}=$ Capital assets replacement, i.e. value of the fixed assets,
$\rho=$ Substitution parameter,
$\delta=$ Distribution parameter,
$\nu=$ Scale parameter, and
$\mathrm{k}=\mathrm{K} / \mathrm{L}$

Constraining the production function to constant returns to scale, i.e. $v=1$, gives us the following relation

$$
\operatorname{Ln}(\mathrm{V} / \mathrm{L})=\operatorname{Ln} / \mathrm{A}_{0}+\lambda \dagger+(1-\delta) \operatorname{Ln}(\mathrm{k})-1 / 2 \rho \delta(1-\delta)(\mathrm{Lnk})^{2} \ldots
$$

where

$$
\lambda=\text { Technical change, and }
$$$$
\dagger=\text { Time. }
$$

Relations-(1) and (2) can be estimated by OLS and coefficients of $\operatorname{Ln}(\mathrm{k})$ and $(\mathrm{Lnk})^{2}$ yield the estimate of $\rho$.

Assuming perfectly competitive product and factor markets, well-behaved production functions and constant returns to scale, differentiating the CES production function with respect to labour, and equating the marginal product to wages, we obtain the following relation.

$$
\operatorname{Ln}(\mathrm{V} / \mathrm{L})=\mathrm{a}_{0}+(1-\sigma) \lambda \dagger+\sigma \mathrm{LnW} \quad \ldots
$$

where

$$
\begin{aligned}
& \mathrm{a}_{0}=\frac{1}{1+\rho} \operatorname{Ln} \mathrm{A}_{0}^{\rho}(1-\delta)^{-1} \text { and } \\
& \mathrm{W}=\text { wages per worker. }
\end{aligned}
$$

The relation (3) may be estimated by the OLS The coefficient of LnW is the elasticity of substitution. Therefore, we estimate elasticity of substitution without directly estimating the CES production function. The attractive feature of indirect estimation is that it does not require capital stock data, the correct estimates of which are not readily available. All it requires is a time-series of output per labourer and the wages. However, the relationship (3) has been derived on the basis of the assumption that factor and product markets are competitive - which is not a very realistic assumption because both these markets suffer from various distortions. These distortions are partly institutional and partly due to the protection and other government policies. For imperfect markets, Katz [11] has derived the following relationship by assuming profit maximisation

$$
\operatorname{Ln}(V / L)=a_{0}+(1-\sigma) \lambda \dagger+\sigma \operatorname{Ln} W+\sigma \operatorname{Ln} \frac{\left(1+E_{w L}\right)}{\left(1+E_{p y}\right)}
$$

where

$\mathrm{E}_{\mathrm{wL}}$ is the inverse of wage elasticity of demand for labour; and

$E_{p y}$ is the inverse of the price elasticity of demand for the product.

Therefore, in a country like Pakistan, where markets are imperfect, the estimates of substitution elasticities obtained through relation (3) involve an assumption that the term $\left(1+\mathrm{E}_{\mathrm{wL}}\right) /\left(1+\mathrm{E}_{\mathrm{py}}\right)$, i.e. the degree of imperfections in labour and product markets, remains constant over time. It may be noted that although factor and product markets in Pakistan are distorted, yet the magnitude of distortion in labour market relative to that in capital market has not changed over time in any significant way, as shown by Irfan [10]. The same is true of the product markets. It can be assumed that the degree of imperfections in labour and product markets in Pakistan has remained constant over time, and equation (3) may be used for estimating substitution elasticities.

For the variable returns to scale ${ }^{2}$, the following relation can be derived from the CES production function.

$$
\operatorname{Ln}(\mathrm{V} / \mathrm{L})=\mathrm{a}_{0}+\left(\underset{1-\sigma}{\frac{\sigma}{1-\sigma}} \lambda \dagger+\sigma \operatorname{Ln} \mathrm{W}+\mathrm{bLnV} \quad \ldots \quad \ldots\right.
$$

where

$$
\mathrm{a}=\frac{\sigma}{1+\sigma} \operatorname{Ln}\left(\mathrm{vA}_{0}\right)^{-1 / \rho}(1-\delta)^{1}
$$

${ }^{2}$ It may be noted that variable returns to scale are incompatible with the Euler theorem and perfectly competitive market. However, in the presence of imperfect markets in Pakistan, the indirect relationship can be derived for variable returns as well. 
The VES production function is also non-linear and is indirectly estimated by assuming the equivalence of marginal product and returns to the factor of production. On the basis of this assumption, we get the following relationship.

$$
\operatorname{Ln}(\mathrm{V} / \mathrm{L})=\mathrm{a}+\mathrm{bLnw}+\mathrm{cLnk}
$$

Elasticity of substitution

$$
=\frac{\mathrm{b}}{1-\mathrm{c}(1+\mathrm{w} 1 / \mathrm{rk})}
$$

The relation (6) is modified to (7) if Hicks neutral disembodied technical change is assumed

$$
\operatorname{Ln}=(\mathrm{V} / \mathrm{L})=\mathrm{a}+\mathrm{bLnw}+\mathrm{cLnk}+\lambda \dagger \ldots
$$

Equation (7) may be estimated by OLS and b and c may be used to estimate the elasticity of substitution which varies with the changes in capital-labour ratios.

Yeung and Tsiang [24] have generalised the VES production function by including the level of employment as additional variable, i.e.

$$
\operatorname{Ln}(V / L)=a+b \operatorname{Lnw}+c \operatorname{Lnk}+d \operatorname{LnL}+\lambda t
$$

where $d$ is the scale parameter.

In order to estimate both the CES and the VES production functions, the data drawn from the Census of Manufacturing Industries (CMI) have been adjusted for the non-response and the errors in the estimates of capital stock. Corrected and adjusted figures are taken frofn Kemal $[13,14]$. It should be noted that the CMI data suffer from the problems which such data in other developing countries also suffer from e.g. in order to avoid taxes, the producers have a tendency to understate production and overstate their costs of production. However, there seems to be no reason to believe that there has been any significant change over time in the understatement of production or the overstatement of cost. Hence, these data can confidently be used to estimate the elasticities of substitution.

\section{ESTIMATES OF SUBSTITUTION ELASTICITIES}

In this section we report the elasticities of substitution between capital and labour in sixteen different manufacturing industries and the manufacturing sector of Pakistan. As pointed out in the introduction, substitution elasticities are not generally invariant with respect to changes in the capital-labour ratios. We shall focus on the estimates obtained through the VES production function which allows for changes in the elasticities with respect to changes in the capital-labour ratios.
However, we shall also present estimates obtained through the CES production function to determine the degree of bias in these estimates and to compare the elasticities of substitution with those in Pakistan reported in the previous studies and those in other developing countries which have been obtained only through the estimation of CES production function.

Elasticities of substitution, assuming both the constant and the variable returns to scale, estimated through the VES production function, are reported in Table 1. It should be evident from the table that elasticity of substitution is statistically significant in only five out of sixteen industries if constant returns to scale are assumed. This shows that the substitution possibilities between capital and labour in different manufacturing industries have been rather limited. If we allow for variable returns to scale, elasticity turns out statistically significant in more industries but still it is significant in less than half of the industries. The elasticities which were insignificant in the cases of footwear, paper and paper board, printing and publishing, rubber and rubber products, non-metallic mineral products and non-electrical machinery, when constant returns are assumed, turn out to be significant when we allow for variable returns to scale. It may be noted that the elasticity of substitution is highest in footwear, leather and leather products, printing and publishing and the miscellaneous industries. These industries have a great development potential in Pakistan and the adoption of appropriate techniques can help a great deal in the evolution of an efficient industrial structure in Pakistan.

In Table 2, we have compared the VES and the CES estimates of substitution elasticities. It shows significant differences in the elasticities obtained through the CES production function compared to those obtained through the VES production function. When the CES production function is specified, substitution elasticity is statistically significant in only three industries ${ }^{3}$ while the elasticity was statistically significant in five industries when the VES production function was specified. Similarly, when variable returns to scale and the CES production function are specified, the substitution elasticities are significant only in five industries; the corresponding number of industries is eight when VES production function is specified. Moreover, not only the significance but the magnitude of elasticity is also affected. Similarly, for the large-scale manufacturing sector as a whole, the CES production function leads to a mis-specification of the production function to the extent that the estimates are not only lower but also are insignificant in the CES specification. These results show that if the CES production function is specified we shall erroneously conclude that in a number of industries and the manufacturing sector as a whole, the changes in relative prices are not going to influence the production techniques.

${ }^{3}$ In order to see if there were any differences in the short-run and the long-run elasticities, we specified Nerlove's lagged adjustment model, i.e. the adjustment is only partial during a year. However, the substitution elasticities are not much affected and have remained insignificant in most of the industries. 
Table 1

Elasticities of Substitution Corresponding to VES Production Function

Value of Elasticity

Name of Industries

When Constant When Variable
Returns to Scale
$\begin{gathered}\text { Returns to Scale } \\ \text { are assumed }\end{gathered}$

Food Manufacturing

$\begin{array}{cc}.1773 & .1212 \\ 1.7429 & -7.9464 \\ .2520 & .3914 \\ -.0804 & 1.7063^{*} \\ -.7284 & 0.1235^{*} \\ 2.6630^{*} & 1.6580^{*} \\ -.6020 & 2.0207^{*} \\ .5565 & .7784^{*} \\ .6030 & .2984 \\ .4133 & -.9000^{*} \\ -.4248 & .1830 \\ .5304 * & .1868 \\ .3668 & .0160^{*} \\ .5568 * & -.1018 \\ 1.1189 * & -.2184 \\ .4030^{*} & 2.0230^{*} \\ .6659^{*} & 0.8791 *\end{array}$

Textiles

Footwear

Paper \& Paper Board

Leather \& Leather Products

Printing and Publishing

Rubber \& Rubber Products

Chemicals \& Chemical Products

Non-Metallic Mineral Products

Basic Metals

Metal Products

Non-Electrical Machinery

Electrical Machinery

Transport Equipment

Miscellaneous Industries

Total: Manufacturing Sector product in the absence of the development of indigenous technology. As a matter of fact, because of the significant and quite high elasticity of substitution for the manufacturing sector as a whole, changes in relative prices of capital and labour will result in reallocation of resources to labour-intensive industries and thus in increasing the gross national product. The welfare in the sense of an increase in output per capita will be increased further if the technology set is broadened and changes in relative factor prices lead to adoption of labour-intensive production technique.

Table 2

Comparison of CES and VES Substitution Elasticity Estimates

\begin{tabular}{|c|c|c|c|c|}
\hline \multirow[t]{2}{*}{ Name of Industries } & \multicolumn{2}{|c|}{$\begin{array}{l}\text { Elasticities correspond- } \\
\text { ing to Constant } \\
\text { Returns to Scale }\end{array}$} & \multicolumn{2}{|c|}{$\begin{array}{c}\text { Elasticities correspond- } \\
\text { ing to Variable } \\
\text { Returns to Scale }\end{array}$} \\
\hline & CES & VES & CES & VES \\
\hline Food Manufacturing & .864 & .1773 & -.0106 & .1212 \\
\hline Tobacco Processing & 1.7161 & 1.7429 & 1.0517 & -7.9464 \\
\hline Textiles & .5189 & .2520 & .6046 & .3914 \\
\hline Footwear & $1.7516^{*}$ & -.0804 & $1.5457^{*}$ & $1.7063 *$ \\
\hline Paper \& Paper Board & -.0512 & -.7284 & $.5946 * *$ & $0.1235^{*}$ \\
\hline Printing and Publishing & $2.6552^{*}$ & $2.6630^{*}$ & $1.9154^{*}$ & $1.6580^{*}$ \\
\hline Leather \& Leather Products & .5630 & -.6020 & $.4199 *$ & $2.0207 *$ \\
\hline Rubber \& Rubber Products & .7877 & .5565 & .3237 & $.7784^{*}$ \\
\hline Chemicals \& Chemical Prods. & .2943 & .6030 & .1182 & .2984 \\
\hline Non-Metallic Mineral Prods. & -.3956 & .4133 & $.4873^{*}$ & $-.9000^{*}$ \\
\hline Basic Metals & .0550 & -.4248 & -.1458 & .1830 \\
\hline Metal Products & .2099 & $.5304^{*}$ & $.5445^{*}$ & .1868 \\
\hline Non-Electrical Machinery & .0790 & .3668 & .0072 & $.0160^{*}$ \\
\hline Electrical Machinery & .1427 & $.5568^{*}$ & .0963 & -.1018 \\
\hline Transport Equipment & -.1677 & $1.1189^{*}$ & -1.1307 & -.2184 \\
\hline Miscellaneous Industries & $1.3724^{*}$ & $.4030 *$ & $1.8455^{*}$ & $2.0230 *$ \\
\hline Total: Manufacturing & $.5824 * * *$ & $.6659 *$ & $.5632^{* * *}$ & $.8791^{*}$ \\
\hline
\end{tabular}

$*$ Significant at 5 percent level.

$* *$ Significant at 10 percent level.

$* * *=\quad$ Significant at 15 percent level.

$*=$ Significant at 5 percent level

It should be quite clear from the preceding discussion that the substitution elasticities remain generally low and insignificant whether we assume constant returns to scale or the variable returns to scale, whether a partial adjustment or the instantaneous adjustment is postulated within the framework of both the CES production function and the VES production function. It follows that the mere removal of distortions in factor markets through appropriate changes in factor prices may not be sufficient to induce a switch-over from the existing capital-intensive techniques to the labour-intensive techniques of production in most of the industechnology set will have to be significantly broadened to bring about the required changes in the levels of capital intensity in each industry. However, it is not to say that the removal of distortions will not play any role in increasing gross national 


\section{COMPARISON WITH SUBSTITUTION ELASTICITIES IN OTHER COUNTRIES AND THOSE REPORTED IN PREVIOUS STUDIES}

It is interesting and useful to compare the substitution elasticities observed in Pakistan with those of other developing countries. Since estimates for other developing countries are available only for the CES production function, our comparison will be restricted to the CES estimates. In Table 3, we compare the elasticities of substitution between capital and labour in various industries of Pakistan, Argentina, Bangladesh and India.

It may be seen from table 3 that substitution elasticities in general are low in the other countries as well. This shows the lack of developing indigenous technologies in the developing economies.

In Table 4, we have compared the substitution elasticities of the manufacturing sectors of Pakistan, Argentina, Chile and Israel. It shows that the elasticity of substitution for Pakistan's manufacturing sector is higher than the elasticity for Argentina's but lower than the elasticity for Chile's and Israel's manufacturing sectors. It all shows that while the substitution elasticities for individual industries are low, they are high and significant for the manufacturing sector as a whole in the developing countries and Pakistan is no exception to that.

There has been only one study to estimate substitution elasticities for different manufacturing industries, i.e. the study by Kazi et al [12]. Results reported in this study confirm the conclusion of that study that the elasticities in the case of individual industries are insignificant. However, the results of the two studies do differ for the manufacturing sector as a whole. While the results of [12] show a lack of substitution between capital and labour, the present study shows the existence of substitution possibilities between capital and labour in the manufacturing sector of Pakistan, though at the 15 -percent level of confidence. The difference in the results for the manufacturing sector in the two studies arise due to different time periods and the differences in the nature of data employed. The study by Kazi et al. was for ten years over the period from 1954 to $1969-70$ while the present study is based on data for eleven years from 1959-60 to 1969-70. However, the mere change in the two time-periods should not make much difference and for each industry results of the two studies are not very different. The main factor responsible for the difference in case of the manufacturing sector as a whole is that the data used in this study are fully adjusted for undercoverage while in [12] unadjusted data are used. Although wages and value added per labourer for each industry remain more or less unaffected by the adjustment process, yet for the manufacturing sector as a whole the wages and value added per worker change significantly because undercoverage varies significantly across the industries over time. Therefore, these adjustments have led to the differences in the results for the manufacturing sector.
Table 3

Comparison of Substitution Elasticities for Developing Countries

\begin{tabular}{|c|c|c|c|c|}
\hline \multirow{2}{*}{ Name of Industries } & \multicolumn{4}{|c|}{ Substitution Elasticities in } \\
\hline & Pakistan & Argentina & Bangladesh & India \\
\hline Food Manufacturing & .09 & 0.28 & 0.37 & \\
\hline Sugar & - & - & - & -.24 \\
\hline Vegetable Oil & & & & .21 \\
\hline Tobacco Processing & 1.72 & $0.22 *$ & 0.60 & - \\
\hline Textiles & 0.52 & $0.26 *$ & $0.34 *$ & \\
\hline Cotton Textiles & & & & 0.04 \\
\hline Woollen Textiles & & & & .06 \\
\hline Jute Textiles & & & & .44 \\
\hline Footwear & $1.76^{*}$ & - & - & - \\
\hline Paper & .05 & 0.21 & $0.48 *$ & 0.94 \\
\hline Printing \& Publishing & $2.66^{*}$ & $0.87 *$ & $0.50 *$ & - \\
\hline Leather & 0.56 & $1.00 *$ & $0.64 *$ & 0.07 \\
\hline Rubber & $0.79 *$ & 0.16 & 0.36 & - \\
\hline Chemicals & .29 & .03 & $0.32 *$ & - \\
\hline Paints \& Varnishes & & & & .19 \\
\hline Soap & & & & .26 \\
\hline Matches & & & & .38 \\
\hline Drugs & & & & .06 \\
\hline Non-Metallic Mineral Products & -.40 & -0.09 & 0.54 & \\
\hline Cement & & & & 0.9752 \\
\hline Glass & & & & .0435 \\
\hline Ceramics & & & & .2594 \\
\hline Metal Products & .21 & & & .1411 \\
\hline Non-Electrical Machinery & .81 & .10 & $.53 *$ & \\
\hline Sewing Machines & & & & .02 \\
\hline Electrical Machinery & & & & -1.3 \\
\hline Electric Lamps & & & & .66 \\
\hline Electric Fans & & & & \\
\hline \multicolumn{5}{|l|}{ Transport Equipment } \\
\hline Bicycles & -.17 & .05 & .38 & 0.05 \\
\hline
\end{tabular}

Sources: Rehman [19], Katz [11], Diwan and Gujarati [7]. $*=$ Significant at 5 percent level. 
A. R. Kemal

Table 4

Comparison of the Elasticities of Substitution of

Manufacturing Sector of the Developing Countries

\begin{tabular}{llll}
\hline Countries & \multicolumn{1}{c}{ Period } & $\begin{array}{c}\text { Production } \\
\text { Function }\end{array}$ & $\begin{array}{c}\text { Value of } \\
\text { Elasticity }\end{array}$ \\
\hline Pakistan & $1959-60$ to $1969-70$ & CES & .58 \\
& & VES & .88 \\
Argentina & 1943 to 1953 & CES & 0.26 \\
& 1954 to 1961 & CES & 0.43 \\
Chile & 1954 to 1965 & CES & 0.21 (Short-run) \\
& & & 0.76 (Long-run) \\
Israel & 1953 to 1964 Bruno's model & 0.76 \\
\hline
\end{tabular}

Sources: Katz [11], Behraman [2], Bruno [5] and the present study.

\section{LIMITATIONS OF THE ANALYSIS}

In this section, we shall discuss limitations of the analysis and the data. At the very outset, we may note that the existing techniques for estimating elasticity of substitution suffer from a number of problems. Both the CES and VES production functions are non-linear, and as such cannot be estimated directly by linear regressions. Though non-linear techniques have been developed to estimate these functions, these estimation procedures are essentially iterative, and very sensitive to the initial values of the parameters chosen. Direct estimation after linearising the function also biases the estimates towards the value around which the function has been expanded. Hence, indirect estimation used in this study remains the best alternative. One of the assumptions under which CES function can be estimated indirectly is that both product and factor markets are competitive, an unrealistic assumption in the case of Pakistan where both factor and product markets are not competitive, and that each factor of production is paid equal to its marginal product. By postulating imperfect markets, an indirect estimation technique has been derived by Katz [11], in which, in addition to wages, the relative degree of imperfections in product and factor markets is also an explanatory variable. However, as discussed earlier, the relative degree of imperfections in product and factor markets has not changed over time in any significant way. Therefore, the bias in the estimates due to indirect estimation is not expected to be large. It may be pointed out that the CES estimates are also biased to the extent that elasticity of substitution is affected by changes in capital-labour ratios. However, this no longer is a problem when we estimate the VES production function.

The estimation problems discussed above are not limited just to Pakistan. All the studies on production functions are confronted with similar problems. Nevertheless, even though we feel that the elasticity estimates are not going to be affected much by these assumptions, we should draw the policy implications by keeping these reservations in mind

\section{POLICY IMPLICATIONS}

Capital-output ratio in the labour-surplus economy of Pakistan is one of the highest in the world. Obviously, reallocation of resources to labour-intensive activities and a switch-over to labour-intensive techniques of production will be instrumental both in accelerating the growth and in improving income distribution. Generally, distortions in factor prices are blamed for higher level of capital intensity in the developing countries. Hence, an appropriate change in the relative prices is always recommended to reduce capital intensity in the country. However, in order to understand the proper role of relative price changes in the choice of production techniques and activities, we must know the elasticities of substitution in the economy. Such elasticities have been estimated in this study for different industries and for the manufacturing sector of Pakistan as a whole.

We have found that the possibilities of substitution between capital- and labour-intensive techniques of production in most of the industries are rather limited. However, the substitution possibilities between different activities do exist. Our finding that the substitution possibilities between production techniques are rather limited in the case of individual industries points to the fact that a mere removal of distortions will not be sufficient to bring about a change from capitalintensive to labour-intensive techniques of production. This result reflects Pakistan's heavy dependence on imports of capital goods plus the fact that the production techniques suited to the factor endowments of Pakistan have not been developed. The absence of the development of appropriate technologies also underscores the fact that Pakistan has been unable to generate sufficient employment for the labour force. The imported technologies are highly capital-intensive and technical change is generally labour-displacing which has resulted in an ever-worsening unemployment problem in developing countries like Pakistan.

From the above discussion, it follows that a lowering of capital-output ratios through adoption of labour-intensive techniques can only be realised if appropriate indigenous technology is developed. The removal of price distortions will induce the 
flow of more resources into developing appropriate indigenous technology. However, for the development of indigenous technology, the changes in relative prices, though necessary, are not sufficient. It follows that the government will have to subsidise the technological development.

While changes in relative prices may lead to the adoption of labour-intensive production techniques only over the long run, the appropriate changes in relative prices will immediately increase social welfare through better allocation of resources amongst various activities. Therefore, removal of distortions from factor prices will not only lead to an increase in welfare over long run by inducing the development of new technology but over short run it will increase welfare through a reduction in the capital-labour ratio by increasing the share of labour-intensive activities in the total output.

\section{CONCLUSIONS}

In the present study we have focussed on three issues. First, whether possibilities of substitution between capital-and labour-intensive production techniques in Pakistan exist or not? Secondly, whether possibilities of substitution exist between different types of activities or not? And, thirdly, whether changes in capital-labour ratio affect the elasticity of substitution or not?

In this study we have found that the elasticity of substitution between capitaland labour-intensive techniques in a number of industries is rather low and insignificant. For example, in sugar, tobacco, textiles, and chemicals, which are some of the most important industries in Pakistan, the possibilities of substitution between capital and labour are negligible. For the manufacturing sector as a whole, the elasticity is high and significant. Therefore, changes in relative factor prices are expected to result in a specialisation in labour-intensive activities, better suited to the factor endowments of Pakistan. Moreover, changes in capital-labour ratios affect significantly the elasticity of substitution and as such the estimates obtained through CES production function are biased. Therefore, we should concentrate on the estimation of VES production function.

A comparison of substituion elasticities for the manufacturing sector of Pakistan with those of the other developing countries shows that the phenomenon of low and statistically insignificant substitution elasticities is not confined just to Pakistan. They are low for most of the developing countries and the estimates presented in this study are consistent with them. This study confirms the results of an earlier study for Pakistan that for the individual industries, elasticities are insignificant but study for Pakistan that for the indive are at variance with the in the case of the manufacturing sectionit-

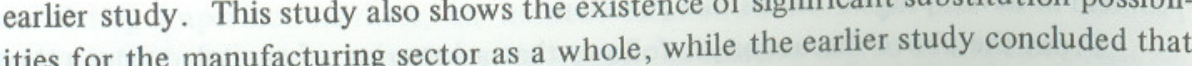
even for the manufacturing sector as a whole the substitution possibilities did not exist. The present study has clearly negatived that conclusion.

Production Functions and the Elasticity of Substitution

There are four most celebrated production functions, viz. the fixed co-efficients, the Cobb-Douglas, the Constant Elasticity of Substitution and the Variable Elasticity of Substitution Production Functions. The elasticity of substitution is zero in the fixed co-efficient production function and unity in the Cobb-Douglas production function. These two production functions are, therefore, not of much interest to us in the present study. In the CES production function, the elasticity of substitution is invariant with respect to changes in the capital-labour ratios. However, in the VES production function, the elasticity varies with changes in the capital-labour ratios.

\section{CES Production Function}

The CES production function was derived by Arrow, Chenery, Minhas and Solow [1] from the basic relationship;

$$
\operatorname{Ln} \mathrm{V} / \mathrm{L}=\mathrm{a}+\mathrm{b} \operatorname{Ln} \mathrm{W}
$$

After allowing for disembodied Hicks neutral technical change and the variable returns to scale, we may write the CES production function as

$$
\mathrm{V}_{\mathrm{t}}=\mathrm{A}_{0} \mathrm{e}^{\lambda \dagger}\left[\delta \mathrm{L}_{\mathrm{t}}^{-\rho}+(1-\delta) \mathrm{K}_{\mathrm{t}}^{-\rho}\right]-\mathrm{v} / \rho
$$

where

$\mathrm{V}=$ Value added,

$\mathrm{L}=$ Labour,

$\mathrm{K}=$ Capital,

$\lambda=$ Rate of disembodied Hicks neutral Technical change,

$\delta=$ Distribution parameter,

$\mathrm{v}=$ Economies of scale parameter,

$\rho=$ Substitution parameter, and

$\sigma=1 / 1+\mathrm{p}$ is the elasticity of substitution.

Subscript $t$ indicates time period.

In the case of constant returns to scale, we set $v=1$, and rewrite the functions 


\section{VES Production Function}

In a CES production function, elasticity of substitution is invariant with respect to changes in the capital-labour ratios. However, the assumption may not hold and in order to draw any meaningful conclusions regarding the substitution of inputs following a change in their prices, it is essential to test whether the capital intensity affects the substitution elasticity or not. Therefore, the need for the estimation of a VES production is obvious.

There are different variants of VES production function derived from different basic relations. However, in this study, we shall be concerned with a VES production function derived by Hildebrand and Liu [9] from the basic relationship that the average productivity of labour is a function of wage rate and capital-labour ratio, i.e.

$$
\operatorname{Ln}(\mathrm{V} / \mathrm{L})=\mathrm{a}+\mathrm{bLnW}+\mathrm{cLn}(\mathrm{K} / \mathrm{L})
$$

Corresponding to the relation (4) we can derive the following relation.

$$
\mathrm{V}=\left[\beta \mathrm{K}^{-\rho}+\mathrm{a} \eta(\mathrm{K} / \mathrm{L})^{-\mathrm{c}(1+\rho)} \mathrm{L}^{-\rho}\right]-1 / \rho
$$

where

$$
\rho=1 / \mathrm{b}-1, \quad \eta=\frac{1-\mathrm{b}}{1-\mathrm{b}-\mathrm{c}} \quad \alpha=\mathrm{a}^{-1 / \mathrm{b}}=(1-\delta) \gamma^{-\rho}
$$

$\beta=\delta \gamma^{-\rho}$ is the constant of integration and after rearranging terms we obtain the following relation.

$$
\mathrm{V}=\gamma\left[\delta \mathrm{K}^{-\rho}+(1+\rho)(\mathrm{K} / \mathrm{L})^{-\mathrm{c} / 1-\rho_{\mathrm{L}}-\rho}-1 / \rho\right.
$$


Table 1 - Continued

\begin{tabular}{|c|c|c|c|c|c|c|c|}
\hline Name of Industries & Intercept & $\begin{array}{c}\text { Coefficients } \\
\text { of } \\
\log W\end{array}$ & $\begin{array}{c}\text { Coefficient } \\
\text { of } \\
\text { time }\end{array}$ & $\mathrm{R}^{2}$ & $R^{-2}$ & F - Ratio & D. W. \\
\hline (1) & (2) & (3) & (4) & (5) & (6) & (7) & (8) \\
\hline Paper and Paper Board & $\begin{array}{l}13.0139 \\
(3.4175)\end{array}$ & $\begin{array}{l}-.0512 \\
(1.0012)\end{array}$ & $\begin{array}{r}-0.0737 \\
(3.1842)\end{array}$ & .7864 & .7330 & 14.73 & .97 \\
\hline Printing and Publishing & $\begin{array}{r}-11.5630 \\
(1.6251)\end{array}$ & $\begin{array}{c}2.6552 \\
(2.7832)\end{array}$ & $\begin{aligned}-.0258 \\
(.06988)\end{aligned}$ & .9110 & & 40.96 & 1.51 \\
\hline $\begin{array}{l}\text { Leather and Leather } \\
\text { Products }\end{array}$ & $\begin{array}{c}4.5774 \\
(0.7718)\end{array}$ & $\begin{array}{c}0.5630 \\
(0.6760)\end{array}$ & $\begin{array}{r}0.05380 \\
(1.2407)\end{array}$ & .3067 & .1333 & 1.77 & 1.10 \\
\hline $\begin{array}{l}\text { Rubber and Rubber } \\
\text { Products }\end{array}$ & $\begin{array}{l}2.0520 \\
(.6601)\end{array}$ & $\begin{array}{c}.7877 \\
(1.8173)\end{array}$ & $\begin{array}{c}0.1032 \\
(2.6529)\end{array}$ & .8372 & .7965 & 20.57 & 2.68 \\
\hline $\begin{array}{l}\text { Chemicals and Chemical } \\
\text { Products }\end{array}$ & $\begin{array}{l}7.0487 \\
(.8935)\end{array}$ & $\begin{array}{l}.2943 \\
(.2795)\end{array}$ & $\begin{array}{c}.0140 \\
(.03070)\end{array}$ & .0117 & -.2354 & 0.05 & .92 \\
\hline $\begin{array}{l}\text { Non-Metallic Mineral } \\
\text { Products }\end{array}$ & $\begin{array}{l}11.3914 \\
(4.6502)\end{array}$ & $\begin{array}{l}-.3956 \\
(1.1687)\end{array}$ & $\begin{array}{l}-.0211 \\
(2.0826)\end{array}$ & .4822 & .3527 & 3.72 & 2.25 \\
\hline
\end{tabular}

Table 1 -Continued

\begin{tabular}{|c|c|c|c|c|c|c|c|}
\hline Basic Metals & $\begin{array}{c}7.5708 \\
(0.9951)\end{array}$ & $\begin{array}{c}.0550 \\
(.0516)\end{array}$ & $\begin{array}{c}.0808 \\
(1.3634)\end{array}$ & .6546 & .5682 & 7.58 & 2.04 \\
\hline Metal Products & $\begin{array}{c}6.4122 \\
(3.5461)\end{array}$ & $\begin{array}{c}.2099 \\
(.8168)\end{array}$ & $\begin{array}{c}.0086 \\
(.5867)\end{array}$ & .3608 & .1800 & 2.26 & 1.03 \\
\hline Non-Electrical Machinery & $\begin{array}{c}7.4529 \\
(1.8457)\end{array}$ & $\begin{array}{c}.0700 \\
(.0137)\end{array}$ & $\begin{array}{r}.01372 \\
(.5627)\end{array}$ & .3944 & .2430 & 2.61 & 1.51 \\
\hline Electrical Machinery & $\begin{array}{c}7.0227 \\
(2.1987)\end{array}$ & $\begin{array}{l}0.1427 \\
(.3163)\end{array}$ & $\begin{array}{c}.0488 \\
(1.4054)\end{array}$ & .4586 & .3233 & 3.39 & 1.82 \\
\hline Transport Equipment & $\begin{array}{c}9.4199 \\
(2.1274)\end{array}$ & $\begin{array}{r}-.1677 \\
(.2769)\end{array}$ & $\begin{array}{c}.0119 \\
(.4261)\end{array}$ & .230 & -.2213 & 0.09 & 1.18 \\
\hline $\begin{array}{l}\text { Miscellaneous } \\
\text { Industries }\end{array}$ & $\begin{array}{r}-1.4819 \\
(.0705)\end{array}$ & $\begin{array}{c}1.3724 \\
(4.5874)\end{array}$ & $\begin{array}{r}.06314 \\
(4.4951)\end{array}$ & .8957 & .8696 & 34.34 & 2.01 \\
\hline $\begin{array}{l}\text { Total Manufacturing } \\
\text { Sector }\end{array}$ & $\begin{array}{c}4.0902 \\
(1.3929)\end{array}$ & $\begin{array}{c}.5824 \\
(1.4119)\end{array}$ & $\begin{array}{c}.0175 \\
(1.0272)\end{array}$ & .7458 & .6823 & 11.74 & 1.77 \\
\hline
\end{tabular}


Table 2

Results of CES Production Function Indirectly Estimated

(Variable Returns to Scale Assumed)

Dependent variable is $\log (\mathrm{V} / \mathrm{L})$

\begin{tabular}{|c|c|c|c|c|c|c|c|c|}
\hline Name of Industries & Intercept & Log W & $\log \mathrm{V}$ & Time & $\mathrm{R}^{2}$ & $\mathrm{R}^{-2}$ & F-Ratio & D. W. \\
\hline Food Manufacturing & $\begin{array}{l}3.4626 \\
(.8044)\end{array}$ & $\begin{array}{r}-.0106 \\
(.0262)\end{array}$ & $\begin{array}{c}.4375 \\
(1.3520)\end{array}$ & $\begin{array}{r}-.0134 \\
(.2616)\end{array}$ & .7581 & .6545 & 7.31 & 1.54 \\
\hline Tobacco Processing & $\begin{array}{r}-18.2883 \\
(1.6699)\end{array}$ & $\begin{array}{l}1.0517 \\
(.8826)\end{array}$ & $\begin{array}{c}1.8316 \\
(1.9977)\end{array}$ & $\begin{array}{l}-.1961 \\
(1.0681)\end{array}$ & .5372 & .3389 & 2.71 & 1.60 \\
\hline Textiles & $\begin{array}{c}.2041 \\
(.0338)\end{array}$ & $\begin{array}{c}.6046 \\
(.8931)\end{array}$ & $\begin{array}{c}.2739 \\
(1.0891)\end{array}$ & $\begin{array}{l}-.0182 \\
(4.092)\end{array}$ & .6723 & .5319 & 4.79 & 1.82 \\
\hline Footwear & $\begin{array}{r}-4.6019 \\
(2.8397)\end{array}$ & $\begin{array}{c}1.5457 \\
(4.8926)\end{array}$ & $\begin{array}{c}.1436 \\
(.8931)\end{array}$ & $\begin{array}{l}-.0458 \\
(1.7045)\end{array}$ & 9079 & .8684 & 23.00 & 1.65 \\
\hline Paper and Paper Board & $\begin{array}{r}-7.8993 \\
(1.4631)\end{array}$ & $\begin{array}{c}.5946 \\
(1.5212)\end{array}$ & $\begin{array}{c}1.2507 \\
(4.2265)\end{array}$ & $\begin{array}{l}-.2144 \\
(5.9915)\end{array}$ & 9399 & .9141 & 36.47 & 1.23 \\
\hline
\end{tabular}

\section{Table 2 - Continued}

Printing and Publishing

Leather and Leather

Products

Rubber and Rubber

Products

Chemicals and Chemical

Products

Non-Metallic Mineral

Products

Basic Metal

Metal Products

Non-Electrical Machinery
$-3.8376$

(2.2754)

18.2783

$(.0845)$

1.6490

(.3486)

.5877

(.1821)

$2.3153-.1458$

(.3487)

$-.2445$

(.1099)

7.1794

(1.7362)
(.1669)

.5455

(2.8531)

.4199

(1.9915)

.3237

(1.0161)

.1182

(.1943)

.4873

$(1.5602)$

.0072

(.0121)
$4.3738-.0920$

(4.5673) (3.7548)

$.9664-.1243$

(1.0877) (6.3093)

$.6860-.0421$

$(3.3550) \quad(.8348)$

$.5524-.0456$

(4.1340) (1.6617)

.9777

$.9681 \quad 102.04$

2.35

.9613

9447

$\frac{7}{2}$ 


\begin{tabular}{|c|c|c|c|c|c|c|c|c|}
\hline Name of Industries & Intercept & $\log W$ & $\log V$ & Time & $\mathrm{R}^{2}$ & $\mathrm{R}^{-2}$ & F-Ratio & D. W. \\
\hline Electrical Machinery & $\begin{array}{c}5.2043 \\
(1.2663)\end{array}$ & $\begin{array}{c}.0963 \\
(.2054)\end{array}$ & $\begin{array}{c}.2026 \\
(.7378)\end{array}$ & $\begin{array}{c}.0158 \\
(.2754)\end{array}$ & .4977 & .2824 & 2.31 & 2.13 \\
\hline Transport Equipment & $\begin{array}{c}.0948 \\
(.2374)\end{array}$ & $\begin{array}{r}-.1307 \\
(.3286)\end{array}$ & $\begin{array}{c}.8513 \\
(3.4021)\end{array}$ & $\begin{array}{l}-.0782 \\
(2.4234)\end{array}$ & .6318 & .4740 & 4.00 & 1.12 \\
\hline $\begin{array}{l}\text { Miscellaneous } \\
\text { Industries }\end{array}$ & $\begin{array}{c}.9565 \\
(.4446)\end{array}$ & $\begin{array}{c}1.8455 \\
(3.3907)\end{array}$ & $\begin{array}{c}.3085 \\
(1.0384)\end{array}$ & $\begin{array}{c}.0820 \\
(3.5761)\end{array}$ & .9096 & .8708 & 23.47 & 2.18 \\
\hline $\begin{array}{l}\text { Total Manufacturing } \\
\text { Sector }\end{array}$ & $\begin{array}{l}2.4256 \\
(.2673)\end{array}$ & $\begin{array}{c}.5632 \\
(1.2496)\end{array}$ & $\begin{array}{c}.1277 \\
(0.1954)\end{array}$ & $\begin{array}{l}.0016 \\
(.0189)\end{array}$ & .7472 & .6388 & 6.90 & 1.70 \\
\hline
\end{tabular}

Table 3

Results of VES Production Function Indirectly Estimated (Constant Returns to Scale Assumed)

Dependent variable is $\log (\mathrm{V} / \mathrm{L})$

\begin{tabular}{lcccccccc}
\hline Name of Industries & Intercept & Log W & Log K/L & Time & $\mathrm{R}^{2}$ & $\mathrm{R}^{-2}$ & F-Ratio & D. W. \\
\hline \multicolumn{1}{c}{$(1)$} & $(2)$ & $(3)$ & $(4)$ & $(5)$ & $(6)$ & $(7)$ & $(8)$ & $(9)$ \\
\hline \multirow{2}{*}{ Food Manufacturing } & 6.0145 & .1053 & .1773 & .0395 & .7011 & .5730 & 5.4722 & 1.23 \\
& $(1.0590)$ & $(0.2359)$ & $(.3774)$ & $(1.0159)$ & & & & \\
Tobacco Processing & -2.23647 & 1.8396 & 1.7429 & .3460 & .3491 & .0701 & 1.2513 & 1.56 \\
& $(.9895)$ & $(1.4083)$ & $(.9022)$ & $(1.4082)$ & & & & \\
Textiles & 3.2117 & .3460 & 0.25198 & .03016 & .6540 & .5057 & 4.4098 & 1.13 \\
& $(.6430)$ & $(.4725)$ & $(.8689)$ & $(.8736)$ & & & & \\
Footwear & 4.0936 & 1.7595 & -.0804 & -.0245 & .9014 & .8591 & 21.3203 & 2.17 \\
& $(2.0114)$ & $(7.8520)$ & $(.5304)$ & $(2.4068)$ & & & & \\
Paper and Paper Board & 15.3963 & .1896 & -.7284 & -.0986 & .8564 & .7948 & 13.9118 & 1.40 \\
& $(4.3018)$ & $(.2920)$ & $(1.8465)$ & $(4.0471)$ & & & &
\end{tabular}


Table 3-Continued

\begin{tabular}{|c|c|c|c|c|c|c|c|c|}
\hline Name of Industries & Intercept & Log W & $\log \mathrm{K} / \mathrm{L}$ & Time & $\mathrm{R}^{2}$ & $\mathrm{R}^{-2}$ & F-Ratio & D. W. \\
\hline (1) & (2) & (3) & (4) & (5) & (6) & (7) & (8) & (9) \\
\hline Printing and Publishing & $\begin{array}{r}-7.3840 \\
(1.4245)\end{array}$ & $\begin{array}{c}2.7878 \\
(4.1517)\end{array}$ & $\begin{array}{l}-.6020 \\
(3.0358)\end{array}$ & $\begin{array}{l}-.0531 \\
(1.9364)\end{array}$ & .9615 & .9451 & 58.4195 & 2.58 \\
\hline $\begin{array}{l}\text { Leather and Leather } \\
\text { Products }\end{array}$ & $\begin{array}{r}-28.9050 \\
(2.0299)\end{array}$ & $\begin{array}{c}2.0630 \\
(2.3282)\end{array}$ & $\begin{array}{c}2.6363 \\
(2.4859)\end{array}$ & $\begin{array}{r}.1311 \\
(2.855)\end{array}$ & .6318 & .4740 & 4.0031 & 2.46 \\
\hline $\begin{array}{l}\text { Rubber and Rubber } \\
\text { Products }\end{array}$ & $\begin{array}{r}-.6657 \\
(.1708)\end{array}$ & $\begin{array}{l}.4708 \\
(.9211)\end{array}$ & $\begin{array}{c}.5564 \\
(1.1248)\end{array}$ & $\begin{array}{c}.0986 \\
(2.5616)\end{array}$ & .8621 & .8030 & 14.5871 & 2.38 \\
\hline $\begin{array}{l}\text { Chemicals and Chemical } \\
\text { Products }\end{array}$ & $\begin{array}{l}1.8462 \\
(.2310)\end{array}$ & $\begin{array}{l}0.1564 \\
(.1607)\end{array}$ & $\begin{array}{c}.6030 \\
(1.5601)\end{array}$ & $\begin{array}{r}-.0153 \\
(.3622)\end{array}$ & .2668 & -.0475 & .84892 & 0.68 \\
\hline $\begin{array}{l}\text { Non-Metallic Mineral } \\
\text { Products }\end{array}$ & $\begin{array}{c}9.4186 \\
(3.4022)\end{array}$ & $\begin{array}{l}-.6772 \\
(1.7536)\end{array}$ & $\begin{array}{c}.4133 \\
(1.3322)\end{array}$ & $\begin{array}{l}-.0218 \\
(2.2540)\end{array}$ & .5859 & .4099 & 3.3150 & 2.02 \\
\hline Basic Metal & $\begin{array}{c}1.2214 \\
(1.1387)\end{array}$ & $\begin{array}{l}.2293 \\
(.2009)\end{array}$ & $\begin{array}{l}-.4248 \\
(.6259)\end{array}$ & $\begin{array}{c}.0735 \\
(1.1723)\end{array}$ & .6729 & .5327 & 4.7996 & 1.96 \\
\hline Metal Products & $\begin{array}{l}2.3461 \\
(.9344)\end{array}$ & $\begin{array}{l}.15633 \\
(.7136)\end{array}$ & $\begin{array}{c}.5304 \\
(2.0425)\end{array}$ & $\begin{array}{l}.0006 \\
(.5323)\end{array}$ & .5995 & .4279 & 3.4926 & 1.87 \\
\hline
\end{tabular}

$\begin{array}{lcccccccc}\text { Non-Electrical Machinery } & 5.1425 & -.04918 & .3668 & .0276 & .5477 & .3539 & 2.8258 & 1.65 \\ & (1.2790) & (.0914) & (1.5404) & (1.1377) & & & & \\ \text { Electrical Machinery } & 3.7310 & -.0764 & .5668 & .0587 & .7304 & .6149 & 6.3213 & 0.97 \\ & (1.3770) & (.2184) & (2.8562) & (1.9405) & & & & \\ \text { Transport Equipment } & 1.3254 & -.1515 & 1.1189 & .05164 & .3991 & .1416 & 1.5498 & 1.92 \\ & (.2092) & (.2984) & (2.0932) & (1.7097) & & & & \\ \text { Miscellaneous } & -5.56869 & 1.4007 & .4030 & .071959 & .9589 & .9413 & 54.4027 & 2.45 \\ \text { Industries } & (2.9593) & (6.9696) & (3.2801) & (7.3399) & & & & \\ \text { Total Manufacturing } & -1.5920 & .4936 & .6699 & .03021 & .9143 & .8776 & 24.8924 & 3.31 \\ \text { Sector } & (6.6865) & (1.919) & (3.7096) & (2.7600) & & & & \end{array}$


Table 4

Results of VES Production Function Indirectly Estimated

(Variable Returns Assumed)

Dependent variable is $\log (\mathrm{V} / \mathrm{L})$

\begin{tabular}{|c|c|c|c|c|c|c|c|c|c|}
\hline Name of Industries & Intercept & Log W & $\log \mathrm{K} / \mathrm{L}$ & $\log L$ & Time & $\mathrm{R}^{2}$ & $\mathrm{R}^{-2}$ & F-Ratio & D.W. \\
\hline (1) & (2) & (3) & (4) & (5) & (6) & (7) & (8) & (9) & (10) \\
\hline Food Manufacturing & $\begin{array}{l}7.4004 \\
(.7917)\end{array}$ & $\begin{array}{c}.0829 \\
(.1678)\end{array}$ & $\begin{array}{c}.1537 \\
(.2956)\end{array}$ & $\begin{array}{r}-.1003 \\
(.1960)\end{array}$ & $\begin{array}{c}.0500 \\
(.7338)\end{array}$ & .7030 & .5050 & 3.55 & 1.22 \\
\hline Tobacco Processing & $\begin{array}{l}17.4640 \\
(1.5530)\end{array}$ & $\begin{array}{r}-3.5746 \\
(1.1000)\end{array}$ & $\begin{array}{r}-6.3131 \\
(1.3056)\end{array}$ & $\begin{array}{r}-9.0964 \\
(1.7795)\end{array}$ & $\begin{array}{c}.9862 \\
(2.3539)\end{array}$ & .5739 & .2899 & 2.02 & 2.23 \\
\hline Textiles & $\begin{array}{r}-30.8861 \\
(3.0630)\end{array}$ & $\begin{array}{c}1.4558 \\
(2.6834)\end{array}$ & $\begin{array}{c}1.1844 \\
(3.7303)\end{array}$ & $\begin{array}{c}1.4759 \\
(3.5494)\end{array}$ & $\begin{array}{l}-.0991 \\
(2.3524)\end{array}$ & .8884 & .8139 & 11.94 & 2.80 \\
\hline Footwear & $\begin{array}{r}-0.9161 \\
(.2127)\end{array}$ & $\begin{array}{c}1.7235 \\
(7.4014)\end{array}$ & $\begin{array}{r}-.2122 \\
(.9633)\end{array}$ & $\begin{array}{r}-.2125 \\
(.8415)\end{array}$ & $\begin{array}{c}.0122 \\
(.2716)\end{array}$ & .9118 & .8529 & 15.50 & 2.91 \\
\hline Paper and Paper Board & $\begin{array}{l}26.0329 \\
(5.5832)\end{array}$ & $\begin{array}{c}-.5011 \\
(1.0526)\end{array}$ & $\begin{array}{l}-.4758 \\
(1.6189)\end{array}$ & $\begin{array}{r}-1.1644 \\
(2.8126)\end{array}$ & $\begin{array}{c}.1269 \\
(1.5469)\end{array}$ & .9381 & .8968 & 22.71 & 1.68 \\
\hline
\end{tabular}

Continued -

Table 4-Continued

$\begin{array}{lrrrrrrrrr}\text { Printing and Publishing } & -.0708 & 2.5353 & -.8847 & -.3256 & -.0082 & .9642 & .9403 & 40.38 & 2.60 \\ & (.0057) & (3.1748) & (1.8565) & (.6584) & (.1113) & & & & \\ \text { Leather and Leather } & -58.7037 & 3.2399 & 3.4444 & 1.7875 & -.0800 & .7299 & .5498 & 4.05 & 2.88 \\ \text { Products } & (2.4354) & (2.8335) & (3.0659) & (1.4763) & (.5362) & & & & \\ & & & & & & & & & \\ \text { Rubber and Rubber } & -2.0794 & .4788 & .6043 & .1264 & .0830 & .8629 & .7715 & 9.44 & 2.37 \\ \text { Products } & (.2406) & (.8672) & (1.023) & (.1871) & (.8884) & & & & \\ \text { Chemicals and Chemical } & -2.5554 & .1687 & .5856 & .4574 & -.0499 & 3.3937-.0107 & .9735 & .88 \\ \text { Products } & (.2911) & (.1765) & (1.5417) & (1.120) & (.9661) & (.3937) & & & \\ \text { Non-Metallic Mineral } & -3.5416 & .1460 & .6224 & .5352 & -.0998 & .8266 & .7110 & 7.15 & 2.27 \\ \text { Products } & (.7228) & (.3711) & (2.7185) & (2.8797) & (3.5748) & & & & \\ & & & & & & & & & \\ \text { Basic Metal } & 36.4702 & .3523 & -2.3155 & -1.0546 & .1411 & .6896 & .4826 & 3.33 & 1.70 \\ & (.7734) & (.2886) & (.6804) & (.5682) & (1.0374) & & & & \\ \text { Metal Products } & -3.2600 & .5016 & .5226 & .3227 & -.0494 & .7269 & .5448 & 3.99 & 2.33 \\ & (.8088) & (.7647) & (2.2557) & (1.6727) & (1.3989) & & & & \\ \text { Non-Electrical Machinery } & .0056 & -0.5495 & 1.0326 & 0.3143 & -.0067 & .8536 & .7559 & 8.74 & 3.05 \\ & (.0019) & (1.5280) & (4.3327) & (3.5397) & (.3786) & & & & \end{array}$


Table 4-Continued

Name of industries

Intercept Log

(1)

(2)

(3)

(4)

(5)

$\mathrm{R}^{2} \quad \mathrm{R}^{-2} \mathrm{~F}$ Ratio D.W.

\begin{tabular}{|c|c|c|c|c|c|c|c|c|c|}
\hline Electrical Machinery & $\begin{array}{r}-10.8960 \\
(2.8991)\end{array}$ & $\begin{array}{c}.2542 \\
(1.2393)\end{array}$ & $\begin{array}{c}1.0806 \\
(6.4305)\end{array}$ & $\begin{array}{c}.8097 \\
(4.2273)\end{array}$ & $\begin{array}{l}-.0708 \\
(2.2068)\end{array}$ & .9322 & .8871 & 20.63 & 1.62 \\
\hline Transport Equipment & $\begin{array}{r}-43.6550 \\
(1.8675)\end{array}$ & $\begin{array}{r}-.3964 \\
(.8693)\end{array}$ & $\begin{array}{c}3.5360 \\
(2.5637)\end{array}$ & $\begin{array}{c}2.2635 \\
(1.8620)\end{array}$ & $\begin{array}{l}-.0749 \\
(1.0295)\end{array}$ & .6192 & .3653 & 2.44 & 1.60 \\
\hline $\begin{array}{l}\text { Miscellaneous } \\
\text { Industries }\end{array}$ & $\begin{array}{r}11.3102 \\
(.4541)\end{array}$ & $\begin{array}{c}1.4818 \\
(6.1541)\end{array}$ & $\begin{array}{r}-.3992 \\
(.3363)\end{array}$ & $\begin{array}{r}-.8649 \\
(.6798)\end{array}$ & $\begin{array}{c}.0527 \\
(1.7549)\end{array}$ & .9618 & .9364 & 37.78 & 2.23 \\
\hline $\begin{array}{l}\text { Total Manufacturing } \\
\text { Sector }\end{array}$ & $\begin{array}{l}10.3000 \\
(1.1790)\end{array}$ & $\begin{array}{c}.3532 \\
(1.3540)\end{array}$ & $\begin{array}{l}.2620 \\
(.7799)\end{array}$ & $\begin{array}{l}-.5575 \\
(1.4056)\end{array}$ & $\begin{array}{c}.0798 \\
(2.1926)\end{array}$ & .9355 & .8926 & 21.77 & 3.23 \\
\hline
\end{tabular}

Table 5

Results of CES Production Function Directly Estimated

(Constant Returns to Scale Assumed)

Dependent variable is $\log (\mathrm{V} / \mathrm{L})$

\begin{tabular}{lcccccccc}
\hline Name of Industries & Intercept & $\log \mathrm{K} / \mathrm{L}^{2}$ & $\mathrm{~L}$ og K/C & Time & $\mathrm{R}^{2}$ & $\mathrm{R}^{-2}$ & F-Ratio D. W. \\
\hline \multicolumn{1}{c}{$(1)$} & $(2)$ & $(3)$ & $(4)$ & $(5)$ & $(6)$ & $(7)$ & $(8)$ & $(9)$ \\
\hline Food Manufacturing & -22.6703 & 3.6910 & -.7528 & .0412 & .733 & .618 & 6.40 & 1.74 \\
& $(.72)$ & $(.98)$ & $(.94)$ & $(1.20)$ & & & & \\
Tobacco Processing & 28.4189 & -2.7251 & 1.5589 & .3974 & .398 & .140 & 1.54 & 1.75 \\
& $(1.03)$ & $(.87)$ & $(1.65)$ & $(1.63)$ & & & & \\
Textiles & -.1948 & .9955 & -.2340 & .0498 & .831 & .758 & 11.47 & 1.75 \\
& $(.07)$ & $(3.12)$ & $(2.79)$ & $(5.47)$ & & & & \\
Footwear & 11.5685 & -.4005 & .2408 & .0176 & .039 & -.374 & .09 & 1.67 \\
& $(.74)$ & $(.20)$ & $(.21)$ & $(.41)$ & & & & \\
Paper and Paper Products & 15.1788 & -.5728 & -.0153 & -.0930 & .855 & .792 & 13.72 & 1.27 \\
& $(.15)$ & $(.05)$ & $(.01)$ & $(5.63)$ & & & & \\
\hline
\end{tabular}




$\log K / L^{2} \quad \log K / C$

Time

(1)

(2)

(3)

(4)

(5)

(6)

(7)

(8) (9)

\begin{tabular}{|c|c|c|c|c|c|c|c|c|}
\hline Printing and Publishing & $\begin{array}{l}13.7688 \\
(3.92)\end{array}$ & $\begin{array}{l}-.6319 \\
(1.58)\end{array}$ & $\begin{array}{c}-.0691 \\
(.50)\end{array}$ & $\begin{array}{l}.0565 \\
(3.09)\end{array}$ & .872 & .817 & 15.84 & 1.92 \\
\hline $\begin{array}{l}\text { Leather and Leather } \\
\text { Products }\end{array}$ & $\begin{array}{l}5.9390 \\
(1.06)\end{array}$ & $\begin{array}{l}1.9966 \\
(2.92)\end{array}$ & $\begin{array}{c}-1.0728 \\
(3.56)\end{array}$ & $\begin{array}{l}.0369 \\
(.90)\end{array}$ & .767 & .667 & 7.69 & 2.29 \\
\hline $\begin{array}{l}\text { Rubber and Rubber } \\
\text { Products }\end{array}$ & $\begin{array}{c}18.2881 \\
(.27)\end{array}$ & $\begin{array}{c}-1.3632 \\
(.16)\end{array}$ & $\begin{array}{l}.5419 \\
(.26)\end{array}$ & $\begin{array}{l}.1215 \\
(3.46)\end{array}$ & .847 & .781 & 12.91 & 2.19 \\
\hline $\begin{array}{l}\text { Chemicals and Chemical } \\
\text { Products }\end{array}$ & $\begin{array}{c}-144.3700 \\
(1.37)\end{array}$ & $\begin{array}{c}-17.1307 \\
(1.45)\end{array}$ & $\begin{array}{c}-2.8892 \\
(1.40)\end{array}$ & $\begin{array}{l}-.0245 \\
(1.18)\end{array}$ & .424 & .177 & 1.72 & 1.16 \\
\hline $\begin{array}{l}\text { Non-Metallic Mineral } \\
\text { Products }\end{array}$ & $\begin{array}{l}6.3490 \\
(1.67)\end{array}$ & $\begin{array}{l}.2371 \\
(.58)\end{array}$ & $\begin{array}{c}-.0196 \\
(.45)\end{array}$ & $\begin{array}{l}-.0222 \\
(1.74)\end{array}$ & .422 & .174 & 1.70 & 1.31 \\
\hline Basic Metals & $\begin{array}{l}1.9035 \\
(.10)\end{array}$ & $\begin{array}{l}-.7460 \\
(.32)\end{array}$ & $\begin{array}{l}-.2020 \\
(.51)\end{array}$ & $\begin{array}{l}.0795 \\
(3.19)\end{array}$ & .683 & .547 & 5.02 & 2.39 \\
\hline Metal Products & $\begin{array}{c}-211.7634 \\
(2.94)\end{array}$ & $\begin{array}{l}28.2624 \\
(3.05)\end{array}$ & $\begin{array}{c}-10.4682 \\
(2.99)\end{array}$ & $\begin{array}{l}-.0125 \\
(1.22)\end{array}$ & .811 & .730 & 10.03 & 1.78 \\
\hline
\end{tabular}

Table 5-Continued

Non-Electrical Machinery

Electrical Machinery

Transport Equipment

Miscellaneous

Industries

Total Manufacturing

Sector
.7013

(.31)

5.7931
$(0.11)$

$-19.8548$

(.26)

$-4.6670$

(.18)

10.7125

(1.76).
(.8769)

(3.23)

.2402

(.04)

3.1926

(.35)

1.4869

(.45)

$-.4200$

(.57)
$-.1735$

(1.59)

.0502

(3.36)

$\begin{array}{lccccc}.03629 & .0254 & .547 & .353 & 2.82 & 1.66 \\ (.02) & (2.46) & & & & \end{array}$

$-.5141$

(.23) (1.40)

.0545

$-.2124 \quad .0936$

(.36) (3.41)

.396

.137

$1.53 \quad 1.93$

$.2778 \quad .0530$

(1.57) (7.94) 
Table 6

Results of CES Production Function Directly Estimated

(Variable Returns to Scale)

Dependent variable is $\log (\mathrm{V} / \mathrm{L})$

\begin{tabular}{|c|c|c|c|c|c|c|c|c|c|}
\hline Name of Industries & $\begin{array}{l}\text { Inter- } \\
\text { cept }\end{array}$ & $\log L$ & $\log K$ & $\begin{array}{r}\log \mathrm{L} \\
\log K^{2}\end{array}$ & Time & $\mathrm{R}^{2}$ & $R^{-2}$ & F-Ratio & D. W. \\
\hline (1) & (2) & (3) & (4) & (5) & (6) & (7) & (8) & (9) & (10) \\
\hline Food Manufacturing & $\begin{array}{c}4.5921 \\
(.6490)\end{array}$ & $\begin{array}{r}-.1065 \\
(.0266)\end{array}$ & $\begin{array}{c}.7005 \\
(.1787)\end{array}$ & $\begin{array}{r}-.1744 \\
(.2130)\end{array}$ & $\begin{array}{c}.1156 \\
(2.0026)\end{array}$ & .9579 & .9299 & 34.17 & 1.16 \\
\hline Tobacco Processing & $\begin{array}{r}-25.31542 \\
(1.8436)\end{array}$ & $\begin{array}{l}13.7452 \\
(3.7186)\end{array}$ & $\begin{array}{r}-8.7882 \\
(3.9343)\end{array}$ & $\begin{array}{c}4.35844 \\
(3.8879)\end{array}$ & $\begin{array}{r}-.0612 \\
(.5442)\end{array}$ & .9660 & .9433 & 42.62 & 3.29 \\
\hline Textiles & $\begin{array}{c}5.0771 \\
(4.1710)\end{array}$ & $\begin{array}{r}-.3643 \\
(.2354)\end{array}$ & $\begin{array}{r}-2.2423 \\
(1.5319)\end{array}$ & $\begin{array}{r}-.3110 \\
(.8483)\end{array}$ & $\begin{array}{c}.2572 \\
(4.8454)\end{array}$ & .9891 & .9818 & 135.56 & 2.23 \\
\hline Footwear & $\begin{array}{l}5.8595 \\
(.8290)\end{array}$ & $\begin{array}{c}.9560 \\
(.2274)\end{array}$ & $\begin{array}{r}-.4110 \\
(.1081)\end{array}$ & $\begin{array}{c}.1127 \\
(.0453)\end{array}$ & $\begin{array}{c}.0885 \\
(.5950)\end{array}$ & .8903 & .8172 & 121.79 & 1.32 \\
\hline
\end{tabular}

Table 6-Continued

\begin{tabular}{|c|c|c|c|c|c|c|c|c|c|}
\hline $\begin{array}{l}\text { Paper and Paper } \\
\text { Board }\end{array}$ & $\begin{array}{l}6.6589 \\
(.3900)\end{array}$ & $\begin{array}{l}2.0709 \\
(.2345)\end{array}$ & $\begin{array}{l}2.1085 \\
(.2403)\end{array}$ & $\begin{array}{r}-.5182 \\
(.3185)\end{array}$ & $\begin{array}{c}.0732 \\
(1.0684)\end{array}$ & .9160 & .8601 & 16.36 & 1.95 \\
\hline $\begin{array}{l}\text { Printing and } \\
\text { Publishing }\end{array}$ & $\begin{array}{r}-15.1530 \\
(1.9253)\end{array}$ & $\begin{array}{r}-14.2790 \\
(1.8257)\end{array}$ & $\begin{array}{l}15.0734 \\
(1.9934)\end{array}$ & $\begin{array}{r}-5.1169 \\
(2.0001)\end{array}$ & $\begin{array}{c}.0654 \\
(1.1828)\end{array}$ & .9866 & .9777 & 110.56 & 1.23 \\
\hline $\begin{array}{l}\text { Leather and Leather } \\
\text { Products }\end{array}$ & $\begin{array}{r}-20.34461 \\
(1.5178)\end{array}$ & $\begin{array}{r}-24.52359 \\
(2.3802)\end{array}$ & $\begin{array}{l}25.9374 \\
(2.4309)\end{array}$ & $\begin{array}{r}-9.6573 \\
(2.6087)\end{array}$ & $\begin{array}{r}-.0768 \\
(.6397)\end{array}$ & .9137 & .8561 & 15.88 & 2.35 \\
\hline $\begin{array}{l}\text { Rubber and } \\
\text { Rubber Products }\end{array}$ & $\begin{array}{l}2.2150 \\
(.2499)\end{array}$ & $\begin{array}{c}4.9771 \\
(5.2807)\end{array}$ & $\begin{array}{r}-3.7418 \\
(.4018)\end{array}$ & $\begin{array}{l}1.1721 \\
(.5028)\end{array}$ & $\begin{array}{c}.0931 \\
(.9654)\end{array}$ & .9306 & .8843 & 20.10 & 2.31 \\
\hline $\begin{array}{l}\text { Chemicals and } \\
\text { Chemical Products }\end{array}$ & $\begin{array}{r}-17.7899 \\
(.4618)\end{array}$ & $\begin{array}{r}-6.4574 \\
(.28988)\end{array}$ & $\begin{array}{l}7.8248 \\
(.3602)\end{array}$ & $\begin{array}{r}-1.2687 \\
(.3343)\end{array}$ & $\begin{array}{l}-.0462 \\
(1.1293)\end{array}$ & .8436 & .7394 & 8.09 & 0.93 \\
\hline $\begin{array}{l}\text { Non-Metallic Mineral } \\
\text { Products }\end{array}$ & $\begin{array}{r}-5.1427 \\
(3.2657)\end{array}$ & $\begin{array}{c}1.0520 \\
(4.5963)\end{array}$ & $\begin{array}{c}0.5028 \\
(2.1797)\end{array}$ & $\begin{array}{c}.0303 \\
(1.2523)\end{array}$ & $\begin{array}{l}-.1064 \\
(5.0868)\end{array}$ & .9888 & .9813 & 131.94 & 2.84 \\
\hline Basic Metals & $\begin{array}{l}26.0573 \\
(1.7656)\end{array}$ & $\begin{array}{r}-1.2401 \\
(.1687)\end{array}$ & $\begin{array}{r}-.1649 \\
(.0257)\end{array}$ & $\begin{array}{r}-.5886 \\
(.2965)\end{array}$ & $\begin{array}{c}.2237 \\
(2.1319)\end{array}$ & .9238 & .8731 & 18.19 & 2.32 \\
\hline Metal Products & $\begin{array}{r}-20.7086 \\
(2.1006)\end{array}$ & $\begin{array}{r}-25.0013 \\
(2.0154)\end{array}$ & $\begin{array}{l}25.9331 \\
(2.1025)\end{array}$ & $\begin{array}{r}-9.6147 \\
(2.0572)\end{array}$ & $\begin{array}{r}-.0039 \\
(.2183)\end{array}$ & .9896 & .9826 & 142.23 & 1.99 \\
\hline
\end{tabular}




\section{REFERENCES}

1. Arrow, K. J., H. B. Chenery, B. S. Minhas and R. M. Solow. "CapitalLabour Substitution and Economic Efficiency". Review of Economics and Statistics. August 1961..

2. Behrman, J. R. "Sectoral Elasticities of Substitution between Capital and Labour in a Developing Economy: Time Series Analysis in the case of Postwar Chile". Econometrica. March 1972.

3. Bhalla, A. S. Technology and Employment in Industry - A Case Study Approach. Geneva: International Labour Office. 1976.

4. Bodkin, R., and L. Klien. "Non-Linear Estimates of Aggregate Production Functions". Review of Economics and Statistics. February 1967.

5. Bruno, M. "Estimation of Factor Contribution to Growth under Structural Disequilibrium”. International Economic Review. February 1968.

6. Bruton, H. "The Elasticity of Substitution in Developing Countries". Research Memorandum No. 45, Williams College, Massachusetts, 1972. (Mimeographed)

7. Diwan, R. K., and D. N. Gujarati. "Employment and Productivity in Indian Industries: Some Questions of Theory and Policy". Artha Vijnana. March 1968.

8. Harris, J. R., and M. P. Todaro. "Wages, Industrial Employment and Labour Productivity: The Kenyan Experience". Eastern Africa Economic Review June 1969.

9. Hildebrand, G., and T. Liu. Manufacturing Production Functions in the United States, 1957. Ithaca, New York: 1960.

10. Irfan, M. "Wage Structure in Pakistan". Unpublished Ph. D. Thesis, Cornell University, Ithaca, New York (U.S.A.). January 1980.

11. Katz, J. Production Functions, Foreign Investment and Growth. Amsterdam: North Holland Publishing Co. 1969.

12. Kazi, S., Zahira Saleem Khan and Seemin Anwar Khan. "Production Relationships in Pakistan's Manufacturing Industries". Pakistan Development Review. Winter 1976.

13. Kemal, A. R. "Consistent Time Series Data Relating to Pakistan's Large Scale Manufacturing Industries”. Pakistan Development Review. Spring 1976.

14. Kemal, A. R. "Sectoral Growth Rates and Efficiency of Factor Use in Large Scale Manufacturing Sector in West Pakistan". Pakistan Development Review. Winter 1979.

15. Kmenta, J. "On the Estimation of CES Production Function". International Economic Review. June 1967.

16. Liu, Y. and L. Fletcher. "A Generalisation of CES Production Function". Review of Economics and Statistics. November 1965. 
17. Nadiri, M. "Some Approaches to the Theory and Measurement of Total Factor Productivity: A Survey". Journal of Economic Literature. December 1970.

18. Oyelabi, J. A. "Tests of Factor Substitution in Nigeria's Manufacturing Sector”. Eastern Africa Economic Review. June 1971.

19. Rehman, A. M. N. "Elasticities of Substitution in Manufacturing Industries of Bangladesh: An International Comparison". Bangladesh Economic Review. April 1973.

20. Reynold, L. C., and P. Gregory. Wages, Productivity and Industrialisation in Puerto Rico. Homewood: Irwin. 1965.

21. Roemer, M. "The Neo-classical Employment Model Applied to Ghanian Manufacturing". Economic Development Report, NC. 225; Cambridge, Massachussettes. (Mimeographed)

22. Sato, R., and R. F. Hoffman. "Production Functions with Variable Elasticity of Factor Substitution: Some Analysis and Testing". Review of Economics and Statistics. November 1968.

23. Sicat, G. P. "Capital-Labour Substitution in Manufacturing in a Developing Economy: The Philippines". The Developing Economies. March 1970.

24. Yeung, P., and H. Tsiang. "Generalised Production Function and Factor Intensity Cross Overs; An Empirical Analysis". Economic Record. September 1972. 